\title{
COMMUNITY-BASED ADAPTATION: A VITAL ASSESSMENT OF THE THREAT OF RISING SEA LEVEL TO THE DEVELOPING COUNTRIES
}

\author{
R S. JOHN BOSE ${ }^{1}$ AND V. YOGANANDAN ${ }^{* 1}$ \\ Department of Marine Science, Bharathidasan University, Tiruchirappalli-620024, Tamil Nadu, India \\ *Corresponding Author: Yoganandan Veeran: E Mail: yoganandan1@gmail.com

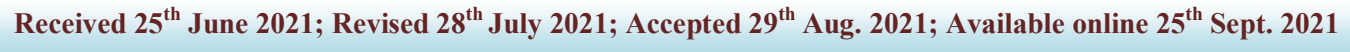 \\ https://doi.org/10.31032/IJBPAS/2021/10.9.1060
}

\begin{abstract}
More than $40 \%$ of the world's population relies on the coastal zone for their habitats. Significantly, sea-level rise due to recent climate change is having a major impact on local and regional coastal communities and their infrastructure. Government authorities have a significant responsibility to their communities for managing the effects of sea-level rise. However, while most local authorities are not well engaged and have don't have a clear understanding of issues arising from sea level rise. This paper identifies some gaps in the legal and policy options available to local government when managing the effects of sea-level rise due to climate change, and outlines the challenges facing local government in adapting to sea-level rise and climate change. The present study suggests some initiatives are necessary to improve the "climatic resistance" against the impacts of sea-level rise. Making preparation against extreme climatic events like cyclones, tsunami storms and etc., which improving the social-economic of the coastal population. From this, we concluded local plans provide a significant overarching tool for implementing strategies to deal with sea-level rise as part of overall growth management currently done for sustainable development. Analyzes the role of local people in coastal areas on how they can develop and practice sea-level rise adaptation in the context of policy framework with the recommendation of integrated planning for coastal events and climate resilience using grounded theory for the long-term sustainable development plan.
\end{abstract}

Keywords: Climate change, sea-level rise, local adaptation, impacts, coastal community INTRODUCTION

The coastal communities are highly resources [1]. However, the coastal dependent on the coastal ecosystem and its ecosystem is highly vulnerable to local sea- 
level rise and extreme climatic events. The coastal ecosystem is also under pressure due to overpopulation, $[\mathbf{2}, \mathbf{3}, \mathbf{4}]$. The inundation risk may lead to dislocation of the human population, damage of human settlements and coastal structures, and loss of agriculture and industrial production [5]. The coastal vulnerability by sea-level rise takes place mainly at the local level where people encounter the impact, build adaptive capacity, and respond at the local level [6].

A regional perspective is important irrespective of adaptation/mitigation to anticipate a range of potential issues, such as physical changes (interruption of sediment supply) or socioeconomic issues (the creation of environmental migrants and refugees) in the coastal regions. Policies that address the forces contributing to local sea-level rise should be framed and actions that reduce the vulnerability and consequences are implemented. The uncertainties of future sea-level rise are now recognized to be inevitable and the local planners must amend their singular traditional paradigm of planning to accommodate multiple scenarios. Such impacts of future uncertainties should be embraced by local decision-makers and policy planners in their short-term and long-term tasks. The coastal communities looking for solutions at the local level to minimize the specific challenges and circumstances, the impact of sea-level rise in each region. The community attitudes to under-adaptation, tolerance of economic opportunity costs, and tolerance of uncertainty seem to determine how aggressive a community will choose to be in developing responses to sea-level rise [7] and most localities have not overcome the political barriers to action. It's recommended that an "Integrated Coastal Zone Management Plan" for the region towards increasing the resilience and adaptive capacity to ensure a long-term sustainable development in the regional coastal areas.

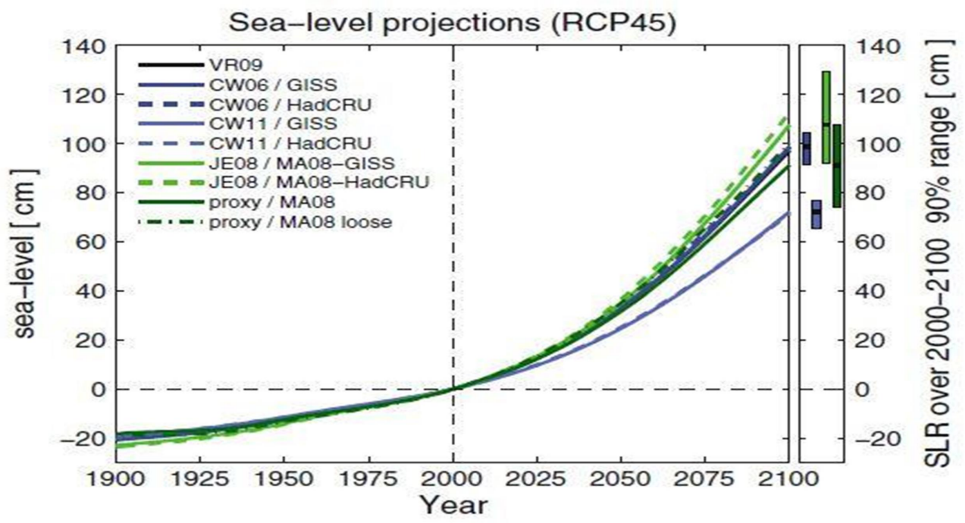

Figure 1: Sea level hind casts and projections for different models calibrated with different temperature and sea level data, Source: Kemp et al., 2011 [41] 


\section{Making a Plan}

Adaptive planning is an ongoing process of coordination and collaboration between the local government and the local community. However, the "Community-based Adaptation" ( $C B A)$ plan is emerging as a new dimension to the adaptation of sealevel rise [8]. A community-based adaptation process should empower the community to plan and cope with the impacts of the sea-level rise [9]. The local people have 'the local practice and indigenous knowledge and networks' to take effective resilience strategy to fight against the adverse situations of the risk in sea level rise [10]. The community-based adaptation plan has the resilience of livelihood to the local people, minimizes the impact of sea-level risk, strengthens the capacity of local civil society and government institutions, and advocacy and social mobilization to address the underlying causes of vulnerability [8]. These coping practices have an important role to accept adaptation strategies and enhance community participation $[11,12$, 13]. In this regard, the local leaders, voluntary agencies, and civil society organizations are working in coastal districts to train the local people for local adaptive options by the technique compatible with ecological, geographical, and unique lifestyles [6].
Most of the coastal protection areas are vulnerable to sea-level rise and high priority for public investment like industrial compounds, recreational facilities, and human settlements. "The Federal Council" is the local level executive council for planning and policymaking on regional coastal management for mitigation and adaptation needs of low-lying coastal protection areas. The council contains all levels of government, private sectors, nongovernmental agencies, and community leaders at the local areas with the local people. The prime role of the federal council is to develop and sustain adaptation strategies, evaluate potential alternatives, facilitate best practices, and build necessary capacity at the local level. The federal council will be relied upon by the government and the local people to develop and sustain collaboration and coordination mechanisms at the national and regional levels that will provide the funding and guidance for research, monitoring, model development, and implementation at the local level. The federal council brought together various experts, panelists, and the local people to discuss and deal with the community with sea-level rise and provide practical tools for local implementation. The Federal council will address the issues of sea-level rise to the local community and will vulnerability assessment and 
adaptation plan local level and raise the issues in local wise with the federal government. Local plans provide a significant overarching tool for implementing strategies to deal with sealevel rise as part of overall growth management currently done for sustainable development.

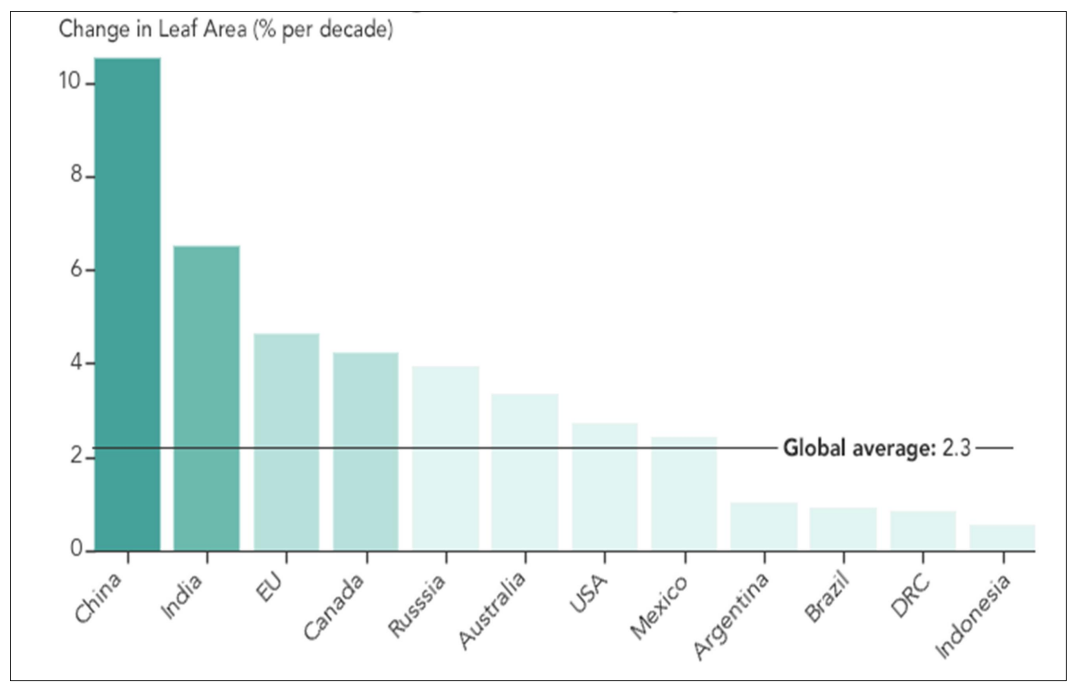

Figure 2: China and India lead in Greening due to Human Activity Source: Adapted from [44]

\section{Develop Local adaptation strategies}

The developing countries lack capabilities to develop the adaptation strategies to reduce their vulnerability to sea-level rise due to lack of resources, technology, and finance. In the coastal region, the adaptation strategies should be based on the aspiration of the adapting communities [14]. The local adaptation strategies derive practical with feasible to the local people to build climate resilience in their coastal region. The part of the adaptation strategies, disaster preparedness, hazard mapping, and warning of climate events in coastal regions must be practiced by the local communities. Conversation of high productive wetland and Planting mangroves and other vegetation in the coastal areas are to absorb water and adapt from coastal erosion [15]. The bio-diverse ecosystems induce the stability of the coastal ecosystem and also the coastal biodiversity: the wetlands, mangroves, coral reefs, and dunes all absorb water and energy that reduce the coastal impacts [16]. The best attempt on climate resilience is to provide alternative livelihood options to the local community and reduce the stress on the coastal infrastructure and both can minimize the impacts of extreme weather events in coastal regions (Table 1). 
Table 1: Major physical impacts of sea-level rise and adaptation responses

\begin{tabular}{|c|c|c|}
\hline \multicolumn{2}{|r|}{ Natural System Effect } & Possible Adaptation Responses \\
\hline 1 & $\begin{array}{l}\text { Inundation flood and } \\
\text { (a) Surge (sea) storm damage } \\
\text { (b) Backwater effect (river) }\end{array}$ & $\begin{array}{l}\text { Dikes/surge barriers, building codes/flood wise } \\
\text { buildings, land use planning/hazard delineation }\end{array}$ \\
\hline 2 & Wetland loss (and change) & $\begin{array}{l}\text { Land use planning, managed realignment /forbid hard } \\
\text { defenses, nourishment/sediment management }\end{array}$ \\
\hline 3 & $\begin{array}{c}\text { Erosion (direct and indirect morphological } \\
\text { changes) }\end{array}$ & Cost defenses, nourishment, building setbacks \\
\hline 4 & $\begin{array}{l}\text { Saltwater intrusion } \\
\text { (a) Surface Water }\end{array}$ & Saltwater intrusion barriers, change water abstraction \\
\hline & (b) Ground Water & Freshwater injection, change water abstraction \\
\hline 5 & Raising water table/impeded drainage & $\begin{array}{c}\text { Upgrade drainage system, polders, change land use, land } \\
\text { use planning/hazard delineation }\end{array}$ \\
\hline
\end{tabular}

Source: Adapted from [42]

\section{Adaptation against coastal disasters}

The frequency and magnitude of coastal disasters have been increasing in recent years which resulted in the loss of human lives, destroying coastal infrastructure, damaging ecological niches, diversifying coastal economies, and disrupting social networks. The local population will harbor knowledge, prepare and responsive institutions for disaster and climate resilience in the eco-fragile coastal region are more likely to be able to minimize the extreme weather events. The local people are living in the low-lying coastal region into the future planning and development process is necessary to frame integrated adaptation strategies for disasters and extreme weather events in coastal regions. The "Community Based Disaster Management" $(C B D M)$ is the best adaptation plan to manage coastal disasters [17]. The plan has to enhance the local and regional governance systems, an early warning system for coastal disasters, and technological improvement for disaster management with the active participation of local people in the disaster-prone area will successfully adopt the coastal population from coastal disasters. The CBDM has to enhance the capacity and knowledge by multilevel governance systems to mobilize the resource to the resilience of various climate events in the coastal region. Much cost-effective planning, location, design, and maintenance measures can be implemented to reduce the risk and vulnerability of roads and infrastructure [18]. Improvement of warning system for climate events in coastal areas and development or repair and maintenance of cyclone shelters to mitigate the impact in the coastal region. Implement post-disaster redevelopment planning is the post adaptation plan for coastal disasters like cyclones and storm surges.

\section{Local adaptation against coastal erosion}

The coasts are more sensitive to climate change impacts of sea-level rise. The projection of IPCC (2007) projected that the mean sea level will increase between 
0.18 and $0.59 \mathrm{~m}$ in 2100 (Figure 1) and $32 \%$ of the current beaches are more vulnerable to shoreline erosion during that time. The sea-level rise exacerbates shoreline erosion, inundates coastal ecosystems, eliminates wetlands, and challenges the human-built structures. The shoreline erosion in general increases in the water depth above the coral reef which allows larger and more forceful waves to pass over them, reaching sandy beaches [19]. The beaches are more sensitive to sealevel rise and up to $45 \%$ of total current beaches are directly impacted by shoreline erosion in 2100 [20]. The coastal infrastructure and its stocks are at increasing risk due to damage by shoreline erosion in low-lying coastal regions [21]. The potential response strategies like dune fixation, beach nourishment, and the building of seawalls to protect the vulnerable coastal urban and industrial regions. The coastal erosion zone has to develop a sustainable ecosystem by ecoengineering techniques such as conservation, restoration, and mitigating coastal erosion [22]. The local government also motivates the people to cultivate the mangrove forest in the erosion zone to minimize the coastal impact. However, implementation of the Integrated Coastal Zone Management Plan for the coastal region with upgrading awareness and building regulation is the effective adaptation against coastal erosion in the ecologically fragile coastal regions.

Local adaptation against coastal aquaculture

The sea-level rise will increase the vulnerability of coastal areas and one of the major effects will be the loss of coastal habitat which provides nesting for sea animals. Global warming is a significant threat to the primary production in the marine environment which leads to affects fish production which in turn marine food chain and human consumption and also affect the economics of fisheries worldwide [23]. The future climate impact is predicted to have a huge stress on the morphological structure and geographical diversity of marine fishes [24]. According to the "Special Report on Emission Scenarios (SRES) A1B, the climate change impacts on marine fish production in 2050 decrease the supply of fish protein to the world population. Overall, 56 million people around the world depend on fishing for their livelihood, and fish production reduced by 4 percent globally. The low fish production in the river delta due to high saline water intrusion will adversely impact the fishing industry. There is a huge urgency to implement mitigation and adaptation strategies to enhance fish production and minimize the climate impact on fish production. Implement "ecosystem conservation policies" to the 
vulnerable coastal region with the participation of the local fishermen community. The local government has to introduce salt-tolerant fish species in the coastal region based on the coastal nature for sustaining the coastal aquaculture.

\section{Local adaptation against agriculture}

In future decade, the agriculture production in the delta region has a huge impact by flood hazards, saline water incursion, and scarcity of groundwater table, prolonged water logging, rapid industrial and urban development and therefore will drastically reduce crops yields [25]. A relevant, robust, and easily operating adaptation framework with all crucial components in agriculture productions can be implemented by the local farmers, all stakeholders, practitioners, policymakers, and scientists. It is necessary to promote the farmers to simple adaptation strategies such as rainwater harvesting and drip irrigation model to the high saline region to agriculture. The water-saving irrigation practice increases the water use efficiency of crops and the economic advantage is marginal due to low-cost water. Encourage the local population to cultivate the crops sensitive to water deficit stress and low micro nutritional status of soil in the high saline coastal region [26]. The implementation options on adaptation in the coastal region are likely to have significant benefits under moderate climate impacts for some cropping systems. In the saline region to encourage the local farmers to cultivate to saline - tolerant crops for sustainable agriculture production [27]. The governmental sector can provide training and assistance to the local farmers in the saline coastal regions for soil fertility management practices and fertilizers usage [28]. In addition, train the local farmers to increase the climate adoptive capacity to agriculture production in the high saline regions and the adapt strategies on an early warning system, climate tolerant genotypes, crop insurance, and climate risk management. The adaptation strategies also included the issues on the climate change with other risk factors, such as climate variability, market risk, and other policy domains for sustainable development in the agriculture sector.

\section{Local adaptation against seawater intrusion}

The coastal regions are threatened by booming population growth and have water scarcity in coastal areas due to reduced precipitation and overexploitation of groundwater resources. In the low-lying coastal regions, the saltwater intrusion in groundwater bodies is higher than in other regions due to overexploitation of coastal aquifers [29]. The soil fertility will thus be diminished and soil nature also deteriorates due to seawater intrusion. In the mixing zone of fresh and saline water, the 
freshwater is getting contaminated by saline intrusion [30]. In addition, the increased salinity in the coastal area will influence soil productivity and more challenging to irrigation of farmland which reduces food production [31]. The best mitigation plan is systematically maintaining the groundwater table levels in coastal areas that may help to reduce the hydrological gradient from seawater. Implementation of integrated water resource management plan in water scarcity regions by wastewater reuse and sustainable plan to avoid the seawater intrusion [32]. The simple adaptation model to motivate the local people for rainwater harvesting should be implemented by the local government. This practice can reduce the water scarcity in coastal areas, providing safe drinking water to coastal communities.

\section{Local adaptation against coastal infrastructure}

The coastal region mound on pressure by human settlement and infrastructure and the coastal areas have more to explore and invest for more infrastructures over the coming years [33]. The coastal infrastructure and industries are adversely impacted by flood and cyclones and therefore need an enhancing resilience of coastal settlement from the impacts of sea- level rise and extreme climate events. Many coastal jurisdictions include climate change in local hazard mitigation plans; because the local people incorporating hazard reduction mechanisms in their land use plans experience less damage from a disasters [34]. As a stand-alone plan, there is no need for any legal prerequisite for implementation or compliance and local jurisdictions allowing, at times even incentivizing, planning in hazardous areas can increase a disasters damaging effects by making development in these areas less expensive through government hazard reduction subsidies [35]. Every county incorporated the coastal city is required to have a local comprehensive land-use plan to guide "the orderly and balanced future economic, social, physical, environmental, and fiscal development of the area". Each plan should be consistent with the state comprehensive plan and appropriate regional policy plan on the sea-level rise when taken as a whole. The local coastal community includes a sea-level rise in their binding policy documents, the majority called for tentative planning in future community infrastructure, development regulations, land use amendments, or beach and inlet management for sustainability or adaptation plan. 
Table 3: Strategies to adapt to an uncertain climate change Strategies to adapt to an uncertain climate change

\begin{tabular}{|c|c|}
\hline & Strategies to adapt to an uncertain climate change \\
\hline (i) & Selecting "no-regret" strategies \\
\hline (ii) & Favoring reversible and flexible options \\
\hline (iii) & Buying "safety margins" in new investments \\
\hline (iv) & Promoting soft adaptation strategies \\
\hline (v) & Reducing decision time horizons \\
\hline & Source: Adapted from [3]
\end{tabular}

\section{Facilitate best practices}

Understanding the public perception of risk in sea level rise and the factors that influence it has been established. It is crucial to generate support for response to sea-level rise. Moreover, such understanding is necessary for framing and communicating policies to the local people to ensure a proper inclusive public participation in critical emerging climatic issues [36]. Develop specific sea-level adaptation strategies for target groups which include decision-makers, community leaders, local people, recreation and tourism groups, media, and local nongovernmental agencies. The adaptation in sea level rise should know to make informed decisions and the local community should be familiar with flood maps, as well as inundation/hazard mapping. The local government should protect the coastal areas by hard engineering structures like sea walls to minimize the threat from high tides, rough waves, rogue waves, storm surges, and inundation at predictable water levels. The coastal polders' structure to reduce the risk of cyclone and storm surges has worsened the situation as the polders "de-linked the flood plains from the rivers [37]. The local house building specialists and other local stakeholders to build a local knowledgebased house building design which includes raising foundations of the house structure and raising platforms within homes where people can take shelter during floods or cyclones and reducing the need to flee from their homes [38]. Facilitate cooperation between states and federal agencies and regional associations to the coastal properties and the coastal properties in vulnerable areas should be insured through long-term planning to minimize the risk in coastal settlements. The local government can able to mobilize a climate fund for local people to assist efforts in sea-levelrise adaptation, and such revenues could use to minimize the coastal disasters and climate refugees [39]. Academic communities will be linked with scientific communities and government agencies to disseminate recent, credible, scientific information on coastal management to the local people. Create awareness to the local people on indigenous climate-allied health impacts and must improve by involving 
local hospitals, primary health centers, voluntary agencies, and federal agencies in coastal regions. Increase awareness of sealevel impacts through print and social media information campaigns, cooperation with schools, and collective activities by local civil societies [40-44]. Moreover, frequent campaigns of cleaning our coastlines are required to deal with climate mitigation, saving energy and reduction of greenhouse gas emissions, and conservation of coastal resources.

\section{CONCLUSION}

This paper focuse on impact assessment of the threat of rising sea levels to the developing countries and emphasizes community-based adaptation. From this, we identified that there is a huge gap between the government policies and strategies in decision-making for local sea level adaptation in developing countries such as India. Hence, we suggest some initiatives are necessary to practice for the future followed by. 1). Improve the "climate change resistance" against the current and predicted impacts of sea-level rise, 2). Making preparation against extreme climate events decreases the socialeconomic cost of the community, 3). To reduce the threats from climate events we have to gather knowledge and adaptive practice from the local community. Local plans provide a significant overarching tool for implementing strategies to deal with sea-level rise as part of overall growth management currently done for sustainable development.

\section{ACKNOWLEDGEMENT}

The authors are thankful to the Department of Marine Science, Bharathidasan University for providing laboratory facility support and encouragement.

\section{REFERENCE}

[1] Wang, H., Li, G., Zhang, Y., Liu, Y., Liu, D., Ding, D., Xu, J., Ma, Y., Qiao, L., Wang, L., 2020. Evolution of Palaeoenvironment of the South Yellow Sea Since the Last Deglaciation. Journal of Ocean University of China 19, 827-836.

[2] Alam, K. and Rahman, M.H., 2014. Women in natural disasters: A case study from southern coastal region of Bangladesh. International Journal of Disaster Risk Reduction, 8: 68-82.

[3] Hallegatte S, Green C, Nicholls R J and Corfee-Morlot J (2013). Future flood losses in major coastal cities Nat. Clim. Change3802-6

[4] Hinkel, J., Lincke, D., Vafeidis, A.T., Perrette, M., Nicholls, R.J., Tol, R.S.J., Marzeion, B., Fettweis, X., Ionescu, C. and Levermann, A., 2014. Coastal flood damage and adaptation costs under 21 st century sea-level rise. Proceedings of the 
National Academy of Sciences, 111(9): 3292-3297.

[5] Nicholls, R.J., 2011. Planning for the impacts of sea level rise. Oceanography, 24(2): 144-157.

[6] Mani Murali, R. and Dinesh Kumar, P.K., 2015. Implications of sea level rise scenarios on land use /land cover classes of the coastal zones of Cochin, India. Journal of Environmental Management, 148: 124-133.

[7] Ayers, J. and Forsyth, T., 2009. Community-Based Adaptation to Climate Change. Environment: Science and Policy for Sustainable Development, 51(4): 22-31.

[8] Deyle, R., W. Butler, and L. Stevens, (2013). Planning Time Frames for Coastal Hazards and Sea Level Rise. Report prepared for the FL Department of Economic Opportunity.

[9] Huq, S. and Reid, H., 2007. Community-based adaptation: A vital approach to the threat climate change poses to the poor. International Institute for Environment and Development (IIED), London, pp. 2.

[10] Reid, H., Alam, M., Berger, R., Cannon, T., Huq, S. and Milligan, A., 2009. Community-based adaptation to climate change: an overview. Participatory learning and action, 60(1): 11-33.

[11] Forsyth, T., 2013. Communitybased adaptation: a review of past and future challenges. Wiley Interdisciplinary Reviews: Climate Change, 4(5): 439-446.

[12] Heijmans, A. and Victoria, L., 2001. Citizenry-based \& developmentoriented disaster response. Experiences and Practices in Disaster Management of the Citizens, Disaster Response Network in the Philippines, Centre for Disaster Preparedness and Citizens' Disaster Response Centre, Philippines, pp 171.

[13] Islam, R. and Walkerden, G., 2015. How do links between households and NGOs promote disaster resilience and recovery?: A case study of linking social networks on the Bangladeshi coast. Natural hazards, 78(3): 1707-1727.

[14] Nakagawa, Y. and Shaw, R., 2004. Social capital: A missing link to disaster recovery. International Journal of Mass Emergencies and Disasters, 22(1): 5-34.

[15] Linham, M.M. and Nicholls, R.J., 2012. Adaptation technologies for coastal erosion and flooding: a review, Proceedings of the 
Institution of Civil EngineersMaritime Engineering. Thomas Telford Ltd, pp. 95-112.

[16] Chmura, G.L., Anisfeld, S.C., Cahoon, D.R. and Lynch, J.C., 2003. Global carbon sequestration in tidal, saline wetland soils. Global Biogeochemical Cycles, 17(4).

[17] Ives, A.R. and Carpenter, S.R., 2007. Stability and diversity of ecosystems. Science, 317(5834): 58-62.

[18] Pandey, B. and Okazaki, K., 2005. Community-based disaster management: empowering communities to cope with disaster risks. Regional Development Dialogue, 26(2): 52.

[19] Keller, G.R., 2002. Rural roads vulnerability reduction assessment, mitigation measures, and training. Natural Hazards Review, 3(4): 139147.

[20] Mimura, N., 1999. Vulnerability of island countries in the South Pacific to sea level rise and climate change. Climate Research, 12: 137-143.

[21] Snoussi, M., Ouchani, T., Khouakhi, A. and Niang-Diop, I., 2009. Impacts of sea-level rise on the Moroccan coastal zone: Quantifying coastal erosion and flooding in the Tangier Bay. Geomorphology, 107(1-2): 32-40.

[22] FitzGerald, D.M., Fenster, M.S., Argow, B.A. and Buynevich, I.V., 2008. Coastal Impacts Due to SeaLevel Rise. Annual Review of Earth and Planetary Sciences, 36(1): 601647.

[23] Mitsch, W.J., 2012. What is ecological engineering? Ecological Engineering, 45: 5-12.

[24] Richardson, A.J. and Schoeman, D.S., 2004. Climate Impact on Plankton Ecosystems in the Northeast Atlantic. Science, 305(5690): 1609-1612.

[25] Sumaila, U.R., Cheung, W.W., Lam, V.W., Pauly, D. and Herrick, S., 2011. Climate change impacts on the biophysics and economics of world fisheries. Nature climate change, 1(9): 449-456.

[26] Chen, X. and Zong, Y., 1999. Major impacts of sea-level rise on agriculture in the Yangtze delta area around Shanghai. Applied Geography, 19(1): 69-84.

[27] Karim, M., Chen, F., Römheld, V., Kirkby, E., Zhang, F. and Zou, C., 2012. Morphological and physiological responses of different Chinese maize genotypes to zinc 
deficiency in relation to drought stress. PhD Thesis: 57-72.

[28] Lakra, N., Kaur, C., Anwar, K., Singla-Pareek, S.L. and Pareek, A., 2018. Proteomics of contrasting rice genotypes: identification of potential targets for raising crops for saline environment. Plant, Cell \& Environment, 41(5): 947-969.

[29] Karim, M.R. and Rahman, M.A., 2015. Drought risk management for increased cereal production in Asian Least Developed Countries. Weather and Climate Extremes, 7: 24-35.

[30] Werner, A.D. and Gallagher, M.R., 2006. Characterisation of sea-water intrusion in the Pioneer Valley, Australia using hydrochemistry and three-dimensional numerical modelling. Hydrogeology Journal, 14(8): 1452-1469.

[31] FAO (Food and Agriculture Organization). (1997). Seawater intrusion in coastal aquifers: Guidelines for study, monitoring and control. Rome, Italy: FAO Water Reports.

[32] Sarwar, M.G.M., 2005. Impacts of sea level rise on the coastal zone of Bangladesh. See http://static. weadapt. org/placemarks/files/225/golam_sar war. pdf.

[33] Lazarova, V., Levine, B., Sack, J., Cirelli, G., Jeffrey, P., Muntau, H., Salgot, M. and Brissaud, F., 2001. Role of water reuse for enhancing integrated water management in Europe and Mediterranean countries. Water Science and Technology, 43(10): 25-33.

[34] OECD, (2006). Infrastructure to 2030: Telecom, Land Transport, Water and Electricity, Organization for Economic Co-operation and Development, Paris.

[35] Nelson, A.C. and French, S.P., 2002. Plan Quality and Mitigating Damage from Natural Disasters: A Case Study of the North ridge Earthquake with Planning Policy Considerations. Journal of the American Planning Association, 68(2): 194-207.

[36] Burby, R.J., 2006. Hurricane Katrina and the paradoxes of government disaster policy: Bringing about wise governmental decisions for hazardous areas. The annals of the American academy of political and social science, 604(1): 171-191.

[37] Lorenzoni, I., Nicholson-Cole, S. and Whitmarsh, L., 2007. Barriers 
perceived to engaging with climate change among the UK public and their policy implications. Global Environmental Change, 17(3-4): 445-459.

[38] Shampa, M. and Paramanik, M., 2012. Tidal river management (TRM) for selected coastal area of Bangladesh to mitigate drainage congestion. International Journal of Scientific \& Technology Research, 1(5): 1-6.

[39] Rawlani, A.K. and Sovacool, B.K., 2011. Building responsiveness to climate change through community based adaptation in Bangladesh. Mitigation and Adaptation Strategies for Global Change, 16(8): 845-863.

[40] Ahsan, D., DelValls, T. and Blasco, J., 2009. The Relationship of National and International Environmental NGOs in Bangladesh and Their Role in Wetland Conservation. Int. J. Env. Res., 3(1): 23-34.

[41] Kemp, A. C., Horton, B. P., Donnelly, J. P., Mann, M. E., Vermeer, M., \& Rahmstorf, S. (2011). Climate related sea-level variations over the past two millennia. Proceedings of the
National Academy

Sciences, 108(27), 11017-11022.

[42] Adger, W. N. (2005). SocialEcological Resilience to Coastal Disasters. Science, 309(5737), 1036-1039.

[43] Nicholls, R. J., \& Tol, R. S. (2006). Impacts and responses to sea-level rise: a global analysis of the SRES scenarios over the twenty-first century. Philosophical Transactions of the Royal Society A: Mathematical, Physical and Engineering Sciences, 364(1841), 1073-1095.

[44] Chen, C., Park, T., Wang, X. et al. China and India lead in greening of the world through land-use management. Nat

Sustain 2, 122-129 https://doi.org/10.1038/s41893-

019-0220-7 